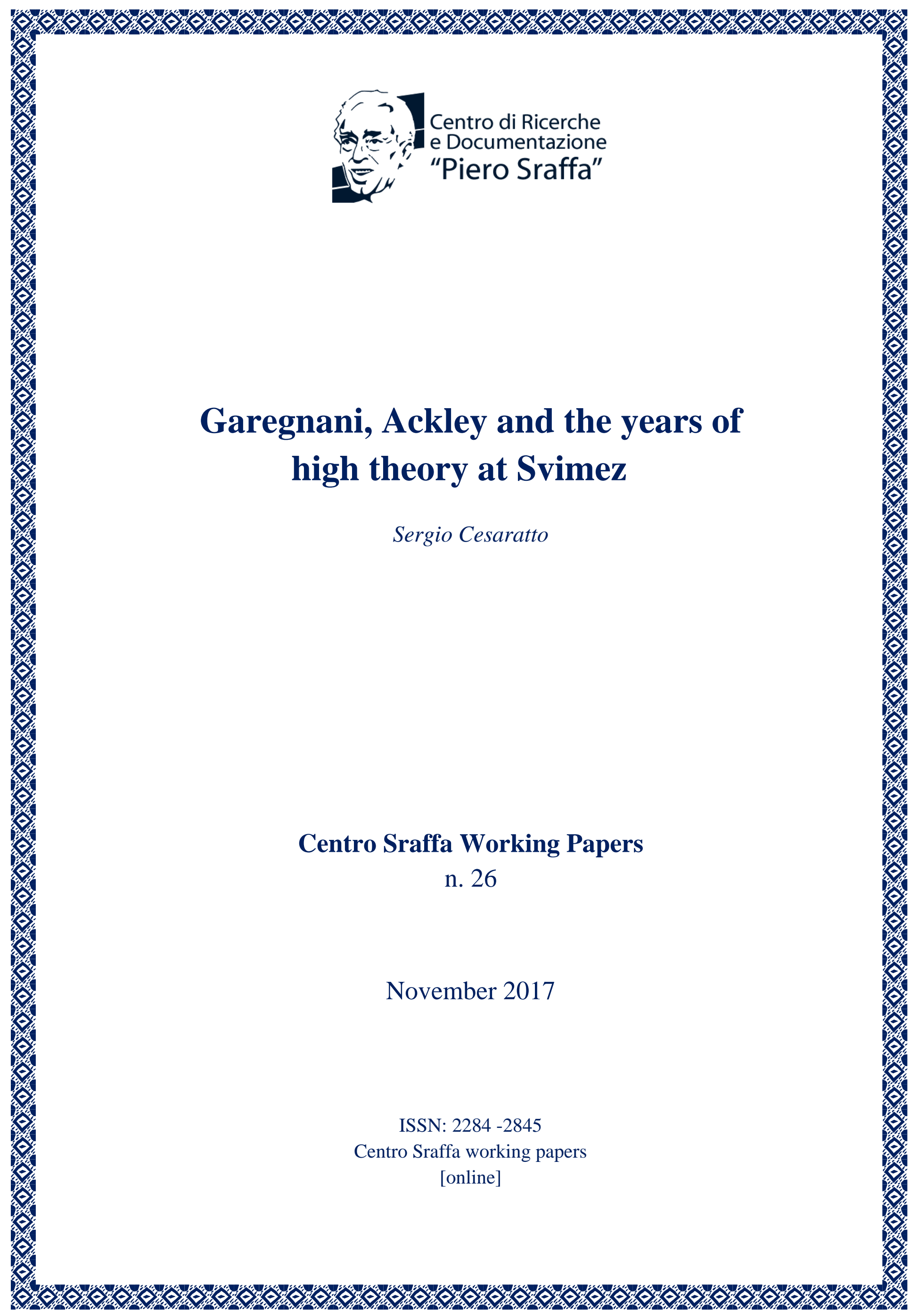




\title{
Garegnani, Ackley and the years of high theory at Svimez
}

\author{
Sergio Cesaratto \\ Università di Siena
}

\begin{abstract}
In the late 1950s, Svimez was an influential research centre on Italian economic and regional policies. It was advised and visited by top international development experts and by leading Italian economists. Pierangelo Garegnani, fresh from his seminal Ph.D. thesis on capital theory at Cambridge, wrote a report for Svimez, published in 1962, on the relevance of Keynes' theory for economies at an intermediate stage of development, like Italy. Interestingly, in 1963 Gardner Ackley published a similar report for Svimez. The theoretical parts of Garegnani's report were published in English in 1978-79 and 2015. In a final applied section, which has not yet been published, Garegnani estimates that a fuller utilisation of productive capacity would have allowed for the creation of 550 thousand additional jobs without problems relating to the balance of payments. In this section, Garegnani also raises several interesting theoretical issues. Ackley's report is an econometric explanation of the Italian 'economic miracle' based on a demand-led growth supermultiplier model - a theoretical approach re-discovered by Bortis and Serrano, and recently taken up by Marc Lavoie and others. A comparison between these two genuine Keynesian approaches looks very promising.
\end{abstract}

Keywords: Garegnani; Ackley; Svimez; Keynesian theory; growth theory

JEL codes: B22; B24; B51

\section{The years of high theory ${ }^{1}$}

In his well-known contribution (Garegnani, 1978-79 [1983]) "Notes on consumption, investment and effective demand" (first published in Italian in 1964-65 by Economia

\footnotetext{
${ }^{1}$ This paper expands upon my introduction to the presentation of Garegnani (2015) in Rome, organised by Svimez and Centro Sraffa in October 2016. The proceedings are published in Italian as Svimez (2017). An abridged version of this paper will appear in a Festschrift volume in honour of Mark Lavoie and Mario Seccareccia edited by J.P. Rochon and H. Bougrine, Edward Elgar (forthcoming).
} 
internazionale), Pierangelo Garegnani (1930-2011) informs us that the essay was based on the first part of "Il problema della domanda effettiva nello sviluppo economico italiano" (Garegnani, 1962), a report written for the Associazione per lo sviluppo dell'industria nel Mezzogiorno (Svimez). Hereafter, this shall be referred to as the Svimez Report. Garegnani also informs us that the report was prepared in 1960-61 and published in 1962 in mimeograph format (forma ciclostilata), with the front page presenting it as a provisional internal report ("Versione provvisoria per uso interno degli uffici"). Nonetheless, the report circulated among colleagues (e.g. Vianello, 2004, pp. 498-501), and was widely known in Italy. ${ }^{2}$ The following table may help the reader to connect the published and unpublished parts of the Svimez report.

\begin{tabular}{l|l}
\hline \multicolumn{1}{c|}{ Svimez original report } & \multicolumn{1}{c}{ Status } \\
\hline $\begin{array}{l}\text { Part I - On the relation between consumption } \\
\text { and investment in a market economy } \\
\text { Chapter } 1 \& 2\end{array}$ & $\begin{array}{l}\text { Revised and published in Italian (Garegnani, } \\
\text { 1964-65) and (abridged) in English } \\
\text { (Garegnani, 1978-79 [1983]) }\end{array}$ \\
\hline $\begin{array}{l}\text { Part II - On the factors that determine the } \\
\text { volume of investment } \\
\text { Chapters 3 \& 4 and conclusions to parts I \& II }\end{array}$ & $\begin{array}{l}\text { Few excerpts in Garegnani (1992); fully } \\
\text { published in English (not revised by the } \\
\text { author) in Garegnani (2015); see Cesaratto and } \\
\text { Mongiovi (2015) }\end{array}$ \\
$\begin{array}{l}\text { Part III - Applications to the Italian situation } \\
\text { during the period 1950-60 } \\
\text { Chapter 5 }\end{array}$ & \begin{tabular}{l} 
Unpublished \\
\hline
\end{tabular}
\end{tabular}

These were intensive years for the young Pierangelo (see Petri, 2001). After obtaining his doctorate at Cambridge in 1958, he was assistant professor to prof. Volrico Travaglini in Rome; in 1961-62 he was visiting MIT, and in 1963 he was given the chair in Sassari. By 1960 he had already published Il capitale nelle teorie della distribuzione (1960) (from his Ph.D thesis) in Italian, a fundamental text for understanding the imperfections of marginalist capital theory from original angles complementary to those of Sraffa (1960). ${ }^{3}$

\footnotetext{
${ }^{2}$ In a chapter review on the Keynesian interpretations of the Italian post-war economic "miracle", Mariano D’Antonio (1973, pp. 159-161) illustrates in sequence Garegnani’s (1962) and Ackley's (1963) respective Svimez Reports as representative of the Keynesian interpretation. The Keynesian position is contrasted to the supply-oriented position held by Pasquale Saraceno, the leading figure of Svimez (ibid., p. 162). Referring again to Garegnani and Ackley, D'Antonio (1997, p. 180) would later write that the «theses on the Italian economy of the economists of Keynesian inspiration have always been unpopular and in the minority». On the impact of Garegnani (1962) on the young Sraffians at the Faculty of Economics in Modena and, indirectly, on the debates among the Italian left, see Vianello (2004, pp. 498-501 and passim).

${ }^{3}$ In the meeting dedicated to the memory of Pierangelo Garegnani held in February 2012 at Roma Tre University, Antonietta Campus related that, in 1960, Sraffa insisted upon a timely translation of Garegnani's book into English, which he regarded as essential for a complete understanding of Production of Commodities, while Garegnani resisted, arguing that a new introduction was necessary in order to take Sraffa's book into account (Garegnani was only able to read Sraffa's book after his own work was already at the galley proof stage). Sraffa insisted, saying that «if Garegnani begins to
} 
In the opening pages of the Svimez Report, Garegnani does not thank anybody, while in "Notes on consumption" he thanks professors Claudio Napoleoni, Sergio Steve, Paolo Sylos-Labini, Volrico Travaglini (Garegnani, 1978-79 [1983], p.21), who were among the most influential Italian economists of the time, for their comments on the manuscript. ${ }^{4}$

From a report by Fabrizio Barca (1997, p. 603), we learn that Svimez - which was founded in 1946 among others by Pasquale Saraceno (1903-1991), who remained its leading personality for decades - was a think tank rather influential on the government in the 1950s. ${ }^{5}$ Barca reports that, according to Saraceno, the post-reconstruction development policies for Mezzogiorno should have resulted in the coordination of two models: that in the Central-North driven by aggregate demand (hereafter AD), and that in the South led by supply side policies (ibid., p. 605). Both Garegnani and Ackley openly challenged the validity of this dichotomy. ${ }^{6}$ This shows the openness of Svimez's milieu.

Frequent foreign visitors to Svimez included the Gotha of development economics, including Colin Clark, Vera Lutz, Richard Echaus, Hollis Chenery and Gardner Ackley. Paul Rosenstein Rodan, Jan Tinbergen and Robert Marjolin were Members of the governing council.

The origins of the Italian boom were widely discussed by international economists (Graziani, 2000, Chapter 2). Moreover, like elsewhere in Western Europe, the idea of economic programming was gaining ground in Italy, often as a side effect of the instabilities of capitalistic economic growth envisaged by Harrod's model. Interestingly, the first Italian official economic program, the Vanoni Plan - named after Ezio Vanoni

write a new introduction, an English translation will never get out» (Campus, 2013, p. 51). In view of Sraffa's well-known reluctance to publish, this sentence was welcomed with some amusement by the audience.

${ }^{4}$ Ackley (1963) thanks Napoleoni, Vera Cao-Pinna, Steve and Paul Rosenstein-Rodan.

${ }^{5}$ Pasquale Saraceno was part of an elite of (antifascist) commis d'etat working in the banking and manufacturing sectors nationalised by Mussolini in the early 1930s, which included, e.g., Raffaele Mattioli, CEO of Credito Italiano (public at that time) and a close friend of Piero Sraffa. On the birth and activities of Svimez see Vitale (2000). A rich illustration of the role played by Claudio Napoleoni (1924-1988) at Svimez, and of the vivid intellectual activities of the association in the late 1950s/early 1960 s is provided by Bellofiore and Beltrame (2004).

${ }^{6}$ In a debate on Garegnani (2015) held at Svimez (2017), the current President of Svimez, Adriano Giannola, defended Saraceno's Keynesianism by emphasising his support for Keynes's view that full employment is not a natural result of laissez faire policies, but requires aggregate demand policies in developed countries and deliberate State intervention in support of industrialisation in late comer countries. The necessity of complementing support for AD with industrial policies and trade controls was emphasized at the same debate by Antonella Palumbo and Massimo Pivetti. While not opposing this, the person most determined to accentuate the novelty of Garegnani's (1962) views was Franklin Serrano. He stressed Garegnani's criticism of the contention (quite popular among development economists) that being a backward, "capital-poor" economy, in which productive capacity is limited, implies that investment is always adjusted to capacity saving (so that the only way to increase investment is to cut consumption). Even Kalecki, in discussing backward economies, would be convinced by this mistaken implication. Garegnani was the first to note that the same Keynesian (and Sraffian) criticism to the saving-investment relation applies to both developed and backward economies (on "Garegnani's 1962 project" see also Moreira and Serrano, 2017). 
(1903-1956), a catholic economist and politician who had refused membership in the fascist party and went on to become minister of the economy between 1948 and 1956 (Magliulo, 2007) - «was certainly prepared in the Roma headquarters of Svimez», and «particularly due to the pen of Saraceno» (Barca, 1997, p. 604; Vitale 2000, pp. 588-602). The Vanoni Plan was well present in Garegnani's (1962) and Ackley's (1963) respective Svimez reports.

\section{The puzzle: is Keynes applicable to economies at an intermediate stage of development?}

The subject of the Svimez Report is precisely the applicability of the Keynesian proposition of the independence of investment from saving, both over the short and long period - what Garegnani (1992, p. 47) would later define, after Kaldor, as the 'Keynesian hypothesis' - to "underdeveloped" economies (as they were defined at that time), or to economies at an intermediate stage of development, like that of Italy. ${ }^{7}$ As Garegnani observes in the introduction to the Report:

economic theory sometimes gives the impression of being divided into two hermetic compartments. The first refers to developed economies, with respect to which it is predominantly admitted that increased consumption does not entail a decline in investments, and could in fact favour an increase in the same, with the exception of situations of general excess in effective demand. The other refers to underdeveloped economies, for which it is generally supposed, on the other hand, that increased consumption would result in a decline in savings and investments (Garegnani, 1962, p. II, my translation [MT hereafter]).

On a similar note, Gardner Ackley opened a paper published in 1957 by pointing out:

During one of my periods of research in Italy, I often noted reservations and doubts among Italian economists regarding the applicability of 'Keynesian' analysis to the study of the economic problems of their country $\left(1957\right.$, p. 271, MT). ${ }^{8}$

And few pages later he observes:

According to some Italian economists, Italy's main economic problem is the scarcity of saving, which is often to be understood as a deficiency of loanable funds with respect to the demand from borrowers (government and firms needing cash for their investment programs). According to these economists, this gives rise to the temptation to resort to

\footnotetext{
${ }^{7}$ It is well known that the Italian economy was (and still is) divided between an industrialised North and an "underdeveloped" South.

${ }^{8}$ Hugh Gardner Ackley (1915-1998) was a professor at the University of Michigan, a member of the Council of Economic Advisers under President Kennedy, and later its Chairman under President Johnson from 1964 to 1968 . He frequently visited Italy where he became ambassador in 1968-1969. In the preface to the second edition of his textbook, Ackley (1978) recalls that "much of the text" of the earlier version (Ackley, 1961) «was [...] written in Italy in 1956-1957, as has some of the best of my other work. Personally, I owe much to this beautiful and tormented land...».
} 
money creation (whether directly or indirectly) in order to provide the required funds. But money creation has inflationary effects, at least beyond a certain limit. Therefore, scarcity of saving means a threat of inflation (ibid., p. 273, MT). ${ }^{9}$

As seen above, this point of view was roughly shared by Svimez president Saraceno. And this stance is not without justification, as Garegnani points out, insomuch as «in underdeveloped economies, an increase in productive capacity is required, rather than an increase in consumer goods» (ibid., p. II, MT). Nevertheless, he also adds that "relatively little attention appears to have been paid to the impact that effective demand factors can have upon the increase in productive capacity for the second type of economy" (ibid., p. II-III, MT, italics in the original).

In a footnote, Garegnani also suggests that this neglect originates with the blurring of underdevelopment problems in planned and market economies:

This is likely due to a little attention being paid to the institutional environment in which the development process has to take place. In fact, it is clear that in a fully planned economy, demand problems can only result from bad planning (ibid., p. III, MT).

What Garegnani suggests, and clarifies in the subsequent lines, is that in unplanned and "underdeveloped" economies, the market forces do not guarantee that the productive capacity - which may or may not be adequate for ensuring full labour employment - will be fully utilised.

Garegnani considers this situation to be even more relevant for economies at an intermediate stage of development, like that of Italy. According to him, the failure to fully exploit the already installed capacity, due to the economic policies' lack of incentives towards an adequate volume of investments, would have "a cumulative effect of lowering the future capacity to accumulate, which is quite relevant for conditioning the development process" (ibidem, MT, my italics). One can appreciate the co-existence within this argument of investment both as a component of $\mathrm{AD}$, and as a determining factor for productive capacity: the weakness of investment under the first profile leads to the underutilisation of existing plants and to the failure to seize the opportunity to fully exploit the accumulation capacity. This naturally goes hand-in-hand also with the failure to re-absorb the structural unemployment characteristic of backward economies. In this respect, Garegnani concludes, the "Keynesian Hypothesis" concerning the independence of investment from saving, over both the short and the long run, has even greater relevance for an economy like that of Italy with respect to more advanced economies, in which an "excess" of investments would encounter bottlenecks in the scarcity of the labour supply:

\footnotetext{
${ }^{9}$ Ackley's position on the applicability of Keynes' economic policies to Italy are discussed in greater detail below. We do not know whether Garegnani ever met the American economist. Ackley's textbook has certainly been credited among Garegnani's students as the most genuinely Keynesian among mainstream textbooks.
} 
For an economy like that of Italy, the principle of the independence of private investment from saving [can] have greater relevance than that which it has in economies where the productive equipment is already adequate to absorb the entire labour supply. In fact, in the second type economies, the failure to utilize potential savings, if contained within certain limits, does not represent considerable losses for the community, since the expansion of the productive capacity would nevertheless reach a limit in the availability of the additional labour required to employ it; this is clearly not the case in an economy like that of Italy (Garegnani, 1962, p.VI, MT).

In fact, in the first type (developed economies), the losses would merely consist of «the output of consumer goods that could be obtained from the unutilized plant and equipment during the time they were left idle» (ibid., p. 82, translation Garegnani 2015, p. 6, my italics); in the second type (underdeveloped economies), on the other hand:

The loss to the community caused by even small deficiencies of investment with respect to full-capacity saving - that is, by even small margins of unutilized productive capacity - then becomes substantial. The loss in fact consists not only of the goods that could have been obtained with the capacity that was left unutilized during the period of deficient demand. It consists also of the goods that could have been obtained in the future from the expansion of the stock of productive equipment had the idle capacity been utilized to produce investment goods. Since this second component of loss, unlike the first, is not temporally limited but is cumulative, it takes on dimensions that surpass by far those of the first component of loss when we consider spans of time measured in decades, the intervals to which growth policy applies. (Garegnani, 1962, p. 83, translation Garegnani 2015, p. 7, italics in the original).

The relevance of the Keynesian analysis for countries like Italy has two interrelated aspects. On the one hand, this analysis denies the tenet of traditional economic policy according to which the larger volume of investment necessary to absorb structural unemployment can derive from a higher propensity to save. On the other hand, it negates that, given existing capacity, there are spontaneous mechanisms to guarantee a level of investment adequate, on average, for potential (or capacity) savings, i.e. those forthcoming from a fully utilised capacity: ${ }^{10}$

when the Keynesian theory denies the traditional proposition according to which every increase in the community's propensity to save corresponds to an increase in private investment, it affirms something that is valid for any market economy, independent of the existence of excess labour. As regards this second, predominantly critical, aspect of Keynes's work, his theory is no less important for the Italian economy than it is for 'rich' economies. It in fact casts light on how the growth of the stock of productive equipment cannot in general be achieved by concentrating economic policy on measures that are likely to stimulate an increase in the community's propensity to save. It instead focuses attention on the factors that determine how high or low will be the level of investment that is necessary for the expansion of the stock of productive equipment and for the creation of new permanent jobs. The increase in the propensity to save, which

\footnotetext{
10 The term "capacity saving" comprises both advanced economies, in which the existing equipment is sufficient, in principle, to employ all the labour force, and backward economies, in which the existing capital stock is not generally sufficient for that purpose. The expression "full employment saving" is in principle valid for the first kind of economies only (but Garegnani, 1962 sometimes employs it for both).
} 
was for the traditional theory the necessary and sufficient condition for that expansion, appears not to be sufficient. It may not even be necessary, since the saving necessary for the increase in investment can come initially from a higher utilization of the available productive capacity and then, in a second stage, from the expansion of productive capacity that is taking place. There is a sense in which it might be argued that the central proposition of Keynes's theory has even greater importance for the Italian economy than for 'rich' economies. (Garegnani, 1962, pp. 81-82, translation Garegnani 2015, p. 6 , italics in the original).

For Garegnani, therefore, a discussion of the Keynesian proposition of the independence of investment from saving and, more precisely, the absence of forces that adjust investment to capacity saving, is relevant for both developed and for catching up economies. The question therefore shifts to «the current discussions in Italy on the wage policy most suitable for favouring employment growth» (ibid., p. IV, MT). The general terms of the question are well known: if the traditional view, in which the supply of saving is seen as the main determining factor of a country's accumulation capacity, were true, an increase of real wages could only have a negative impact on investment due to a lower average propensity to save; on the other hand, the validity of the Keynesian view leads us to wonder whether an increase in real wages might not act as a stimulus to private investment.

\section{Garegnani's argument in theory}

Part I of the Svimez Report was published long ago (see the table above), and its main propositions are therefore well known: Garegnani shows how the results of the critique to the marginalist capital theory that Sraffa (1960) and himself (Garegnani, 1960) had just published were functional to free Keynes from the various ties that still bound his theory to marginalism, which allowed its rapid reabsorption within the traditional alveus as an approach limited to special periods of investment depression. More specifically, those outcomes proved the non-generality of the marginal demand function of investment as negatively elastic to the interest rate. The interest rate could therefore no longer be regarded as the price that brings (capacity) saving and investment decisions into equilibrium. Once the invalidity of this marginalist legacy is proven, the most innovative proposition of the General Theory is ring-fenced: within the limits of existing capacity it is the level of saving that adjusts to the investment decisions through variations of output (or rather of the degree of capacity utilisation).

In my opinion, this is the most convincing reconsideration of Keynes' contribution to heterodox theory. This view clashes with other popular interpretations, largely influenced by Joan Robinson, which underline other aspects of Keynes' thought, such as uncertainty, expectations and animal spirits as determining factors for investment decisions. These are seen by Garegnani as elements that are too subjective and nebulous 
to serve as the basis for a solid accumulation theory (1979, p. 114-116). The two Pieros were also fully concordant on this issue. ${ }^{11}$

Garegnani's reconsideration of the innovative and traditional aspects of Keynes is also useful for rejecting mainstream Keynesianism - represented today, inter alia, by Stiglitz and Krugman -, which confines the Keynesian case to periods of deeply depressed animal spirits, when investment appears inelastic even to lowering the interest rate, or 'liquidity traps', when monetary policy fails to adjust the real long term interest rates to the level (possibly negative) necessary to bring investment to full employment level (Garegnani, 1962, pp. 56-64, 1978-79 [1983], p.56). The theory that investment is independent of saving over the short term, while it is in line with capacity saving (on average) over the long term, is unfortunately also shared by some heterodox scholars who believe in the long term validity of Say's Law. ${ }^{12}$ The criticism of the marginal capital theory naturally leads us to deny the automatic adjustment of investment to capacity saving, both over the short and long term.

In Part II of the Svimez Report, Garegnani (2015) goes even beyond these results, asking himself about the mechanism that leads capacity saving to adjust to investment over the long term. Beyond that, he explores the objective, long term determinants of investment, and the relationship between the real wage level and investment decisions. His response to the first question is that, like in the short term, when greater investment decisions generate a corresponding increase in the saving-supply - within the limit of the existing capacity - through variations of output, in the long run the installation of a larger capacity due to the greater utilisation of capacity will allow for a future potential saving supply adequate for an even larger scale of investment. In short, while saving adjusts to investment through variations in the degree of capacity utilisation in the short period, this adjustment takes place through variations in the scale of capacity over the long period. This is even more clear if we take the case of a volume of investment inadequate for generating a full utilisation of the current capacity: while in the short run this will only imply a lower degree of utilisation of the equipment, over the longer term this will lead to a destruction of excess capacity and, therefore, to the adjustment of potential capacity saving to the persistently lower investment level: ${ }^{13}$

\footnotetext{
${ }^{11}$ See Garegnani’s exchanges with Joan Robinson in Eatwell and Milgate (1983, pp. 70-78) and in Garegnani (1979); see also Garegnani (1976, Section 5). Sraffa's distrust of the subjective elements of economic analysis is forcibly brought to the surface by the manuscripts (e.g. Fratini, 2016; see also Bharadwaj, 1978, based on the conversations with Sraffa).

12 This "heterodox" position is even less founded than the marginalist one, since it does not indicate any adjustment mechanism of investment to capacity saving - see e.g. Cesaratto's (2006) criticism of Foley and Michl's growth model.

${ }^{13}$ Similar adjustments will take place, although in slower and much more complicated ways, in the labour supply through a larger (lower) utilisation of the industrial reserve army and demographic factors including immigration. The adjustment, although at a different pace, of capacity saving and of the labour supply to output growth - explained, in turn, by the $\mathrm{AD}$ - may result in the "optical illusion" that capitalism does not generally suffer, over the very long term, from excess capacity and structural unemployment (Garegnani, 1992, fn. 24).
} 
It follows then that the principle of the independence of investment from saving, which in the short period manifests itself in a shortfall of investment relative to the savings obtainable from the full utilization of productive capacity, can in the long period also manifest itself in a smaller expansion of productive capacity, and therefore in lower levels of full-employment saving. (Garegnani, 1962, p. 78, translation Garegnani 2015 p. 4).

With regard to the second question concerning the ultimate determinants of investment, Garegnani fundamentally sticks to the idea that investment is mainly an induced component of $\mathrm{AD}$, explained by what he calls "final demand", plus a component which is explained by technical progress, and it is therefore independent of final demand (ibid., pp. 91-92, translation Garegnani 2015, pp. 11-12). The latter, in turn, is defined as «the demand whose purpose is not the further production of goods within the economy», therefore including the «domestic demand for consumer goods» [private and public] and «exports net of imports» (ibid., p. 92, translation Garegnani 2015, p.12).

While I shall come back to this definition, investment demand is excluded by final demand (except for the share explained by technical progress), insomuch as it depends upon and it is explained by it. Here, Garegnani explicitly recalls both the "accelerating principle" and the ordinary experience, whereby it is the demand for commodities that, by pressing productive capacity, justifies its expansion (ibid., p. 93, translation Garegnani 2015, p. 12). That which has concealed this fundamental principle of economic development is the traditional idea that investment adjusts to capacity saving, with the consequence that «investment and the growth of the productive system appeared to be completely independent of the markets for goods», with the expansion of the latter coming about «only as a consequence of the growth of the productive system, without any possibility of a reversal of the relation between cause and effect» (ibid., pp. 93-94, translation Garegnani 2015, p. 13).

In order to respond to the third question concerning the influence of real wages upon investment, we are deferred to the study of the effects of the variation of real wages upon consumption and exports, the variables that, in turn, determine induced investment. ${ }^{14}$ Garegnani's response is quite articulated (1962, pp. 98-104, translation 2015 pp. 15-20). On the one hand he maintains that higher real wages can have a positive impact on investment due to a greater final demand for consumer goods; on the other, higher wages can have a negative impact on exports and the balance of payments.

\footnotetext{
${ }^{14}$ It can be noted here that Garegnani tends to exclude a mechanical impact of distribution upon accumulation, both in terms of the Cambridge equation, according to which it is the rate of accumulation decided (in a vacuum) by capitalists that determines distribution, and in terms of the Marglin and Bhaduri model, in which for some "regimes" the rate of profit directly affects investment decisions (see Cesaratto, 2015, pp. 157-158 and pp. 167-179). Garegnani also excludes the possibility that earned/retained profits (internal finance) affect investment decisions, since the theory of effective demand would lead us to look at capitalists' income as the outcome of investment decisions, rather than a precondition (Cesaratto, 2015, p.168). One capitalist privilege naturally consists of access to external finance, or rather money/credit creation by banks, in order to finance investments and other luxury expenses, but this is a different and more consistent Keynesian/Kaleckian story (Cesaratto, 2017a/b).
} 
Garegnani extends his considerations to the effects of increased real wages upon technical progress. While I defer the reader to Garegnani's original text, now available in English, we shall now turn to an unexpected "empirical" Garegnani, which is naturally not lacking in interesting theoretical puzzles.

\section{Garegnani's argument in practice}

Contrary to some prejudiced interpretation, Garegnani has always shown an extraordinary interest for applied economics and (full employment) economic policy as the ultimate aim of economic theory, and has always urged his pupils to carry out both theoretical and empirical work. ${ }^{15}$ In the third (unpublished) empirical part of the Svimez Report, Garegnani examines the question of whether during the period 1955-60 - which overlaps both the "economic miracle" years and the first part of the planning period of the Vanoni Plan - the country could have realised an even greater level of investment in order to generate 350 thousand additional jobs (as a result of a greater productive capacity), without reducing consumption levels, through a fuller utilisation of the existing capacity, and without generating unsustainable balance of payments pressures. ${ }^{16}$ The main tenet is that, given the additional investment's distribution over six years, the new capacity progressively installed would have facilitated subsequent investment (Garegnani, 1962, p. 120). In order to assess the feasibility of his plan, including the direct and indirect effects of additional investment, Garegnani employed a variety of statistical sources and hypotheses, including those adopted by the Vanoni Plan itself and the (then) recently released first input/output table for the Italian economy.

According to Garegnani's estimates, an additional investment of 875 billion Italian liras (at their real 1953 value) over the aforementioned period would have achieved the targeted employment increase without any reduction in the consumption levels of those already employed (ibid., p. 142). According to his estimations, the absence of this additional investment resulted in a missed «increase in employment that might be defined as 'Keynesian' (i.e. an increase in employment obtained simply from an

\footnotetext{
${ }^{15}$ See Cesaratto (2011). According to Aldo Tortorella (2013), a mentor of Garegnani and the cultural head of the Italian Communist Party when the party was at its height in terms of influence over the Italian and foreign intelligentsia, it was difficult to convince the young Garegnani to go to Cambridge and conquer his fears of alienating himself from the Italian political struggle (see also Ciccone, 2012, pp. 2-3). Having said this, as a matter of priority given the lack of time, Garegnani later regarded research on capital theory as central to his scientific endeavour and, eventually, to his political commitment. He clearly and rightly considered the critique of capital theory as the ultimate analytical challenge to traditional theory.

${ }^{16}$ It should be notes that the actual performance of the Italian economy during this period already surpassed the Vanoni Plan's forecasts. This might show that the Vanoni Plan underestimated the ability of capacity saving to adjust to a higher accumulation rate through a fuller utilisation of capacity and the instalment of new capacity, as shown by Ackley (1963). Garegnani (1962) tried to show that even better results could have been reached.
} 
increase in current effective demand)» (ibid., p. 144 MT), amounting to 60-70 thousand workers over each of the six years; not a considerable figure per se. However,

[t]his 'Keynesian' unemployment that extended over the six years in question (1955-60) resulted in a loss of growth in terms of industrial productive equipment that could have provided 350,000 additional jobs, capable of absorbing $32 \%$ of the 'open' unemployment. Therefore, a relatively small 'Keynesian' unemployment seems to explain a considerable 'structural' unemployment over a period of just six years (ibid., p. 144). ${ }^{17}$

On this basis, Garegnani wonders why the private sector did not execute those investments, and the answer is that the demand for products was not deemed to be sufficient «to justify this additional expansion of productive capacity» (ibidem). Therefore, the obstacle to additional investment during the period in question was certainly not an excessive level of consumption, and, in fact, a smaller increase in real wages would have negatively affected accumulation (ibid., p. 143).

\section{A comparison with Ackley}

There are several similarities between Garegnani's and Ackley's Keynesianism. Although this is not the right place for a full presentation of Ackley's views, a number of analogies with Garegnani can be drawn. The first concerns the importance that both economists attributed to Knut Wicksell as the best example of neoclassical General Equilibrium and the standard for assessing the novelties of Keynes' General Theory. Garegnani argued that Keynes' acceptance of the marginalist (and Wicksellian) investment demand function (based on the real side of marginal theory) ${ }^{18}$ led the Cambridge economist to defend the most innovative part of the General Theory - the proposition that saving adjusts to investment via changes in output - by proposing a novel monetary determination of the interest rate (the liquidity preference theory). However, Hicks, Modigliani and others immediately showed that, like old wine in new bottles, this determination was not in conflict, at least over the long period, with the prevalence of the Wicksellian full-employment, natural interest rate within the economy (from this, Garegnani derived the importance of the criticism of the real part of the dominant theory).

Ackley (1961, p. 402) would agree with Garegnani that Keynes' theory of the interest rate «had to be a theory other than the Classical one, or the rate of interest

\footnotetext{
${ }^{17}$ According to Garegnani, the additional employment would have actually been more considerable, since it included 200 thousand additional jobs in the service sector (ibid., p. 145 et seq.). The original investment in the manufacturing sector would have allowed for the production of the investment goods necessary for that expansion, which, in turn, would have reinforced the utilisation rate of the newly installed equipment in the manufacturing sector.

${ }^{18}$ Interestingly, Ackley (1961, p. 503) understood very well that Keynes's investment function was ultimately based on "capital deepening".
} 
would admit by the back door the Classical doctrine of automatic stabilisation of aggregate demand». ${ }^{19}$ Likewise, the American economist does not overemphasize the novelty of liquidity preference theory. Having rejected the idea that Keynes' novelty could reside in wage rigidity, he recalls the limited interest elasticity of investment as «something Keynes stressed» (ibid., p. 405). However, we do not expect and find Ackley making any radical attempt to detach Keynes from traditional theory.

Another similarity is in the importance that both economists attributed to the autonomous component of AD as an explanation of growth. More specifically, Ackley's (1963) interpretation of Italy's economic growth from 1951 to 1960, to which we shall return shortly, is based on the supermultiplier model. ${ }^{20}$ As seen above, Ackley was critical of the Italian economist's dominant attitude of dismissing the relevance of the General Theory to the Italian economy. In Ackley $(1957,1961)^{21}$, however, the American economist apparently seems to reach the traditional conclusion that the

Keynesian remedy for unemployment is obviously not applicable in this presumed state of affairs [the Italian structural unemployment]. An increase in aggregate demand (e.g. increased government expenditure, or encouragement of consumption expenditure or exports) would not increase employment, it would only create inflation $[\ldots]$ Unemployment is structural, not the result of inadequate demand. What is required to eliminate it is not less but more saving (Ackley, 1961, p. 543).

Ackley is indeed well aware that «this prescription for unemployment seems to be just the opposite of Keynes' prescription», but maintains that the two are not inconsistent. His (rather laborious) argument claims that the principle that it is AD that determines output is not abandoned. This is so because while traditional economists take for granted the full employment of existing capacity, in his reasoning it is assumed that AD is adequate for fully utilising present capacity. ${ }^{22}$ Moreover, it is taken for granted that

\footnotetext{
${ }^{19}$ Ackley understands Keynes' definition of "Classical economists" as encompassing both Ricardo (and the proper classical school) and the marginalist economists. In Ricardo, the absence of the notion of the interest rate as the equilibrating price in the saving-investment market makes it clear that Ackley (and Keynes) was actually referring to the marginalist economists alone. As Garegnani has argued (1978-79 [1983], pp. 25-28), the fact that both Ricardo and the marginalists believed in Say's Law does not imply that they believed in it for the same reasons.

${ }^{20}$ The supermultiplier is only briefly alluded to in the earlier version of Ackley's textbook, where he notes the difference between Harrod's warranted growth rate and Hicks' (1950) equilibrium growth path arising «from [Hicks's] assumption of growing autonomous investment» (Ackley, 1961: p. 524 fn. 12). It is well known that, in the original Hicksian supermultiplier model, autonomous demand consists exclusively of autonomous investment. A simple supermultiplier model is presented in the second version of the textbook (1978, pp. 250-251).

${ }^{21}$ Chapter XX of Ackley (1961, pp. 588-589) contains excerpts of the 1957 paper in Italian, while Chapter XIX contains a section devoted to the economic problems of Italy (pp. 542-549).

${ }^{22}$ Ackley actually proposes a two-phase policy:

the contrast between this formulation and the usual Keynesian doctrine is more apparent than real. The typical Keynesian remedy against unemployment, the request for greater spending (either an increase in both components, C and I, or an increase in I without a reduction of C) refers to a single instant or period of time. The remedy to unemployment for Italy, which requires an increase in $I$ to the detriment of $C$, refers to two periods of time. A simple change in the composition of aggregate demand - more I and less C - does not affect aggregate demand or
} 
«investment demand is (at present) practically unlimited, and any reduction of consumption would be more or less automatically offset by increasing investment», an assumption that Garegnani rejected even as a working hypothesis. In truth, Ackley warns that: «If it [investment demand adequate to capacity saving] were not so, reduced consumption would reduce output and employment today, and it would not make greater output and employment possible tomorrow, either» (ibidem). ${ }^{23}$ Ackley (1957, 1961 ) is thus somehow aware that being a "poor capital" country does not necessarily mean that investment is adequate for capacity saving, although less markedly than Garegnani.

The scarcity of productive capacity does not only take on the form of a general aggregate shortage, but also that of bottlenecks in specific "heavy" industries (such as steel, concrete, or electricity) where substitutes are non-existent or of lower quality (1957, p. 287). In this regard, Ackley expresses the preoccupation that, although a "restrictive wage policy" might set "more resources free for investment" 24 with regard to certain "heavy" industries (e.g. from automobile production to steel plant production), it might lead to a decline in demand in other "light" industries (such as textiles) and a "release" of inappropriate resources in order to increase capacity in the heavy industries, so that they would just be left idle. What is needed, he concludes, «is not more investment in general nor less consumption in general» and, in recalling wartime economies, «intervention [...] may have to take a more direct and detailed character than general measures of fiscal and monetary policy» (Ackley, 1961, p. 589). Although fearful of the negative effects of direct "microeconomic" controls (in contrast to the indirect controls of aggregate monetary and fiscal policies), Ackley does not exclude their necessity in "capital-poor" economies (ibid., p. 590). ${ }^{25}$

Ackley's (1963) analysis of the Italian development experience during the 1950s is quite relaxed with regard to the insufficiency of capital stock (and, if anything, is more

present employment; it is uniquely devoted to favouring greater employment during a subsequent time period. It is nevertheless true that, within the limits posed by productive capacity, it is the total dimension, and not the composition, of total demand that matters for the actual employment level. But if aggregate demand is currently adequate for the functioning of the economy at the limit of capacity, and if capacity is limited by the scarcity of capital, then a change in the composition of current global demand (in terms of investment) can allow for a greater level of employment in the future with respect to that which would have been realised without such a qualitative change (Ackley, 1957, p. 278, MT, italics in the original).

${ }^{23}$ Ackley is rather sceptical that, in the Italian situation, «factor price changes can... secure full employment of labour». Nonetheless he considers the absence of the factors' substitution to be too extreme an assumption, also taking into account other adjustment mechanisms - e.g. the indirect substitution mechanisms that act through changes in the composition of consumers' demand, or international specialisation as explained by the Heckscher-Ohlin theorem (1961, pp. 546-547). The reference to the indirect substitution mechanisms through the consumption goods' substitutability for consumers recalls Garegnani meticulous illustration of marginal theories (e.g., 1962, p.12; 1978-79 [1983], p. 29), as well as Ackley's reference to a "socially-tolerable wage level" (or "decent" level) as a floor to price-adjustment mechanism, recalls Garegnani's interpretation of the Classical economists.

${ }^{24}$ Ackley uses this little Keynesian figure of speech in Ackley (1961, p. 549).

${ }^{25}$ After all, Vianello (2004) reports that the discussions in Modena shifted from Garegnani's (1962) to the economics of controls debated during the same years at Cambridge. 
concerned about obtaining an adequate degree of utilisation of the capacity created in the accumulation process). In fact, the model he adopts can be assimilated to an ultraKeynesian supermultiplier, in which «the first two components of demand (consumption and investment) are considered by the model as dependent on the level and on the structure of production, and are therefore endogenous variables», while the «other two components (State spending and net exports), are instead considered exogenous variables» (ibid., p. 3, MT). ${ }^{26}$

Investment is explained by the acceleration principle (ibid., p. 21), while no importance is attributed to the interest rate «for reasons of a theoretical nature, as well as for reasons derived from the direct observation of facts» (ibid., p. 20). Ackley disaggregates the total fixed investment and considers it as autonomous when influenced by public policies, like in agriculture and residential construction (ibid., pp. 33-34). ${ }^{27}$ Public works are definitively considered autonomous.

The main conclusions of Ackley's Svimez Report can be summed up as follows:

i) limitations on the supply side have generally not constituted a major obstacle to the development of the Italian economy over the period in question, which can thus be regarded as demand-led (pp. 63-64 and passim).

ii) The ability of capacity to adjust to demand is attributed to a short-term flexibility in the employment of existing resources and, over time, to investment (ibid., p. 64).

iii) "Embodied" technical progress and economies of scale would explain the growth of labour productivity ${ }^{28}$ (ibid., pp. 65-66).

iv) A reduction in the average propensity to consume was accompanied by a rise of autonomous spending (e.g. public consumption, public support for investment in social housing and agriculture; net exports).

v) All in all, «the constant post-war development [...] has to be related to a favourable concatenation of events, which has led to a continuous increment of autonomous spending» (ibid., pp. 79, 81). Most of the «propulsion has been derived from net exports and from investments in agriculture and housing», while government consumption and investments have played a stabilisation role in the growth of effective demand (p. 83; see also Ciocca, Filosa and Rey, 1975, p. 292 and passim).

vi) The continuation of Italy's development would require a persistent increase in autonomous demand (ibid., p. 84).

\footnotetext{
26 The reference to "net exports" rather than exports as the exogenous variable, since imports are clearly endogenous, is justified by the desire to keep the analysis simple (ibid., pp. 2-3; see also below, section 6).

${ }^{27}$ Given the importance of State owned enterprises in the Italian economy, investment in transport and communication networks (and even in manufacturing) could also be considered autonomous; the difference between different types of investment is one of degree, Ackley argues (ibid., pp. 34-36), and depends on the passage of time: investment in public infrastructure, agriculture and residential dwellings should all be considered endogenous over decades (but autonomous over shorter periods).

${ }^{28}$ Ackley also attributes some space to "capital deepening."
} 
Striking analogies can be drawn between Ackley's and Garegnani's results, specifically with regard to the role of autonomous/final demand in driving investment and effective demand, and the significant adaptability of productive capacity in supporting demand growth by both reorganising the existing resources and by rapidly operating the newly installed equipment.

\section{Issues left open by Garegnani}

The first issue regards the notion of "final demand" as the ultimate determining factor of investment. ${ }^{29}$ Garegnani's (1962, p. 92, translation Garegnani 2015, p. 12) interpretation of final demand also includes induced-consumption - consumption that basically depends upon income and, more specifically, on real wages - as well as government spending and net exports. However, it is disputable that an induced component like wage-consumption might drive a second induced component, namely investment. In fact, it would be more consistent to include in final demand only that part of consumption that is independent of income, namely autonomous (credit-driven) consumption, public consumption (including the portion of public investment that does not depend upon expected demand), and exports (to which I shall return shortly). This does not imply that the real-wage level does not have an impact on demand and investment. In fact, it will affect them through variations in the social marginal propensity to consume, this being however a level and not a growth effect, as I shall later point out.

Moreover, Garegnani curiously seems to commit the same mistake as Kalecki by only including net exports (viz. exports net of imports) in the final demand (Kalecki's "external markets"). ${ }^{30}$ In order to understand why this is not correct, it is sufficient to consider that if we applied the same logic to public spending, only deficit spending would have an expansive effect against the result, for instance, of the balanced budget multiplier theorem (in fact, neither Garegnani nor Kalecki commit this second mistake, and include all government spending in their respective final demand and external markets). ${ }^{31}$

\footnotetext{
${ }^{29}$ A second determinant is technical progress. With regard to this influence, Cesaratto, Serrano and Stirati's (2003) opinion diverges from that of Garegnani.

30 See Serrano (2008, pp. 13-14) on this "mistake", and Cesaratto (2015, pp. 156-157) on the similarities between Garegnani's final demand and Kalecki “external markets".

31 In short, Garegnani and Kalecki move away from the definition of aggregate demand: $\mathrm{AD}=\mathrm{C}+\mathrm{I}+\mathrm{G}+(\mathrm{E}-\mathrm{M})$ (where the symbols are the standard textbook expressions), and exclude investment from final demand/external markets, since it is an induced component. Similarly, however, that part of consumption that also depends on (earned) income, and imports (which also depend on income) are induced components, and should therefore be excluded from final demand. We are therefore left with autonomous consumption, government spending, and exports as components of final demand. These components are ultimately all financed by credit/money creation by banks (Cesaratto, 2016, $2017 \mathrm{a} / \mathrm{b})$.
} 
A second issue regards a puzzle that Garegnani puts forward at the very end of the empirical part of the Svimez Report. As noted above, in the Report he studied the possibility of creating 550 thousand additional jobs in Italy (350 thousand in manufacturing, plus 200 thousand in the tertiary sector) by increasing investment over a period of six years, estimating that this was possible through a greater degree of utilisation of the existing capacity, and by operating the progressively newly installed equipment, without harming the balance of payments equilibrium. However, Garegnani leaves us with a Harrodian type question (although Harrod is never quoted in the Report $)^{32}$ as to whether this additional investment is justified from the standpoint of expected demand:

In fact, it must be considered that the increase of income that would arise from an expansion of industrial and tertiary activities (the only ones capable of providing additional employment) would not, on its own, be sufficient to deliver the demand for the products obtained with the expansion in question. In fact, a part of that income would be saved, or is directed to either imported goods or goods and services originating from agriculture. This would result in a demand void that can only be filled by further investments and exports, or an increase in consumption. If this void were not to be filled, the additional plants could not be profitably utilised and, there would not be an underlying incentive to make the investments necessary to create them (ibid., p. 150, MT).

Garegnani's estimates in this regard are pessimistic. That is to say that the increment in output and income that would result from an increase in productive capacity such as to employ 550 thousand additional units would not spontaneously generate an adequate corresponding increment in demand, thus making the relative investment unjustified:

in the hypotheses adopted here, the demand originating from a general increase in employment in the industrial and tertiary sectors could alone provide the demand for only $65 \%$ of the additional production. Had additional demand of a different origin not been provided, the new productive capacities, even if installed, could not have been utilised: their utilization would have had to occur with losses (ibid., p. 154, MT).

Garegnani's proposed solution is that an increase in demand, in the form of either additional investment - which would only however delay the problem ${ }^{33}$ - or increased exports and/or consumption, would have been necessary:

the demand void that... is created would have to be filled by a further increase in investment (resulting in additional productive capacities, from which the same problem would then reappear), or by an increase in exports, or by a general increase of consumption of the products of the industrial and tertiary sectors. The problem could have been initially resolved by the demand for investment necessary to expand the

\footnotetext{
32 This might reflect Garegnani's scepticism concerning the prevalent growth models at the time (ibid., p. II), but he does not elaborate on this point.

${ }^{33}$ In the subsequent passages, Garegnani seems to suggest agriculture and the provision of public housing as sectors where further investment could be possible (notably, the residential construction sector is an autonomous/non-capacity-creating component of $\mathrm{AD})$.
} 
agricultural and construction sectors accordingly to the expansion of the demand directed towards them, but once that expansion were realised the problem would reassert itself (ibid., pp. 154-155). ${ }^{34}$

The Svimez Report therefore concludes with this pessimistic tone regarding the structural inadequacy of $\mathrm{AD}$ in capitalism. That which Garegnani suggests to fill this "demand void" - either further investment, which would only however delay the problem, or an increase in exports (or consumer demand) - closely resembles the problem posed by Michal Kalecki in his famous 1967 essay on Tugan-Baranowski and Rosa Luxemburg, which is ideally representative of the two solutions: either the production of capital-goods to produce additional capital-goods, or the development of "external markets". Similarly, Ackley's solution to stabilise growth lies in an adequate growth of autonomous demand (Ackley, 1963, p. 84).

\section{Final remarks}

In my view, a rationalisation of some of these open questions is now within reach after the recent increasing popularity of the supermultiplier approach widely proposed by Sraffian scholars like Heinrich Bortis (1997), Franklin Serrano and others, which is inspired, inter alia, by Garegnani (1962) and Kalecki (1934, 1967) (to whom we might add Ackley, 1963). ${ }^{35}$ In stating this, I am aware of the limitations of the models in economics, of which Garegnani has always warned his students. However, a model like the supermultiplier model can be useful for checking the relations and conclusions implicit to complex economic arguments (a method suggested by Alfred Marshall). For instance, with regard to the exclusion of induced (wage) consumption from "final demand" (or from "external markets"), which should be restricted to the non-capacity creation/autonomous component of $\mathrm{AD}$, the supermultiplier analysis allows us to conclude that, ceteris paribus, variations in real wages have a level effect upon income (and upon the normal growth path), via the variation of the marginal propensity to consume, but not a growth effect. A variation in real wages, however, would have an impact upon the growth rate in the transition from a normal growth path to a new one (each characterised by a different propensity to consume). The question therefore becomes empirical, and further research might shed some light on this issue.

This result does however not confirm the "wage-led growth" purported by the neoKaleckian literature, since we are talking about two different models. Although Garegnani's ambiguity with regard to the direct effects of changes in real wages upon investment decisions seems to offer some support for the neo-Kaleckian model - as Marc Lavoie promptly pointed out to me in a private e-mail immediately after the

\footnotetext{
${ }^{34}$ In a footnote, Garegnani remarks that: «In our hypotheses regarding the expansion of the tertiary sector, the demand void would also have been partially filled initially by the demand for investment goods destined for the tertiary sector» (ibid., fn. 1, p. 155).

${ }^{35}$ Marc Lavoie (2016a/b) acknowledged the path-breaking work of Sraffian economists.
} 
publication of Garegnani (2015) - in view of the supermultiplier analysis we know that this phenomenon is relative to the transition between two normal paths. As previously stated, this transition can be extremely important from a practical point of view, but it is nevertheless a rigorous clarification obtained through the supermultiplier model, and therefore cannot be seen as a validation of the neo-Kaleckian model. ${ }^{36}$

It can also be said that, with the increased evidence of its stability, the tenacious criticism to the supermultiplier model by some Sraffian scholars (Palumbo and Trezzini, 2003), who assert that it presupposes a growth rate in autonomous demand adequate for inducing an investment level and accumulation rate such as to absorb capacity saving (so that capacity saving would be the ultimate determinant of a normal growth path), has finally been proven unfounded. On the opposite, in the supermultiplier model capacity saving adjusts to investment as determined by the average pattern of autonomous demand in the given historical, economic and political circumstances (Cesaratto, 2015; Freitas and Serrano 2015, 2017). The idea that growth is driven by "final demand" or by "external markets", two largely coincident concepts, is particularly useful for the analysis of financial crises in capitalism. The key insight is that autonomous demand is sustained by credit/money creation by banks with a consequent indebtedness of households (autonomous consumption), governments (public spending), foreign States (centre-periphery unbalanced or neo-mercantile growth) (Cesaratto, 2017a/b). ${ }^{37}$ The next step in the supermultiplier analysis is a full integration with the analysis of economic cycles in capitalism as determined by cycles of credit expansion and deflation. This would be a step forward from the Minskian analysis, somehow associated to the old marginalist tradition of waves of financial optimism and pessimism (represented, e.g., by A. Marshall, I. Fisher, W. Mitchell, R. Hawtrey). ${ }^{38}$

Garegnani (1962) shows that since its inception (Sraffa, 1951, 1960; Garegnani, 1960), the Modern Classical Theory far to be an ethereal and non-concrete component of heterodox economics, represents an open and consistent approach to distribution and accumulation theory, and to the most pressing problems of the real world.

\footnotetext{
${ }^{36}$ Hein (2017) seems to make this mistake, believing that the results obtained using the supermultiplier model prove the neo-kaleckian theory. It should not be forgotten that the neo-kaleckian models are full of unsustainable hypotheses, as pointed out by Sraffian economists, including Committeri (1986), Vianello (1989), Ciampalini and Vianello (2000), Petri (1994), Palumbo and Trezzini (2003), Trezzini (2011), Cesaratto (2015), Freitas and Serrano (2015, 2017).

${ }^{37}$ Neo-Schumpeterians would perhaps include the indebtedness of companies driven by technological competition associated with major innovations.

${ }^{38}$ For an early critique on these theories, see D.H. Robertson, who, at the start of his "heterodox phase" (which lasted until the early 1930s), wrote: «Granted that [the entrepreneurs'] states of mind are immediately responsible for industrial dislocation, it does not follow that they are spontaneously generated; it seems only natural, in absence of proof, to give him the benefit of the doubt, and assume that they are at least induced, however irrationally, by external facts. Hence this objection also to the search for such facts fall to the ground» (Robertson, 1915, p. 9).
} 


\section{References}

AA.VV. (2013), In ricordo di Pierangelo Garegnani, Centro per lo studio di Roma (CROMA), Università Roma Tre.

Ackley, G. (1957), Analisi "keynesiana" e problemi economici italiani, Moneta e Credito, 10(39), 271-293.

Ackley, G. (1961), Macroeconomic Theory, Macmillan, New York.

Ackley, G. (1963), Un modello econometrico dello sviluppo italiano nel dopoguerra, Giuffrè, Milano, available at: www.svimez.info/images/pubblicazioni/monografie/m_19.pdf

Ackley, G. (1978), Macroeconomics: Theory and Policy, Macmillan, New York.

Barca, F. (1997), Storia del capitalismo italiano dal dopoguerra ad oggi, Laterza, Bari.

Bellofiore, R. and Beltrame, G. (2004), L'insegnamento dell'economia politica come problema, in: C. Napoleoni, G. Garofalo, and A. Graziani (eds), La formazione degli economisti in Italia (1950-1975), Il Mulino, Bologna.

Bharadwaj, K. (1978), Classical Political Economy and the Rise to Dominance of Supply and Demand Theories, Orient Longman (second revised edition, Calcutta, University Press India, 1986).

Bortis, H. (1997), Institutions, Behaviour and Economic Theory: A Contribution to Classical-Keynesian Political Economy, Cambridge University Press, Cambridge.

Campus, A. (2013), L'inizio dell'attività di ricerca di Garegnani e "il solco aperto dall'opera di Sraffa", in: AA.VV. (2013), video available at: http://www.centrosraffa.org/PierangeloGaregnaniMemorialLecture.aspx

Cesaratto, S. (2006), A Reply to Michl, Cambridge Journal of Economics, 30(6), 985-987.

Cesaratto, S. (2011), L'eredità di Garegnani è nella politica economica, http://politicaeconomiablog.blogspot.it/2011/10/leredita-di-garegnani-e-nellapolitica.html

Cesaratto, S. (2015), Neo-Kaleckian and Sraffian Controversies on the Theory of Accumulation, Review of Political Economy, 27(2), 154-182.

Cesaratto, S. (2016), The State Spends First: Logic, Facts, Fictions, Open Questions, Journal of Post Keynesian Economics, 39(1), 44-71.

Cesaratto, S. (2017a), Initial and Final Finance in the Monetary Circuit and the Theory of Effective Demand, Metroeconomica, 68(2), 228-258.

Cesaratto, S. (2017b), Beyond the traditional monetary circuit: endogenous money, finance and the theory of long-period effective demand, Quaderni DEPS, no. 757. 
Cesaratto, S. and Mongiovi, G. (2015), Pierangelo Garegnani, the Classical Surplus Approach and Demand-led Growth. A Symposium, Review of Political Economy, 27(2), 103-110.

Cesaratto, S., Stirati, A., and Serrano, F. (2003), Technical change, effective demand and employment, Review of Political Economy, 15(1), 33-52.

Ciampalini, A. and Vianello, F. (2000), Concorrenza, accumulazione del capitale e saggio del profitto. Critica del moderno sottoconsumismo, in: M. Pivetti (ed.), Piero Sraffa: contributi per una biografia intellettuale, Carocci, Roma.

Ciccone, R. (2012), Pierangelo Garegnani: rifondare la teoria economica, Moneta e Credito, 65(259), 243-267.

Ciocca, P., Filosa, R., and Rey, G.M. (1975), Integration and Development of the Italian Economy, 1951-1971: A Re-Examination, BNL Quarterly Review, 28(114), 284,320.

Committeri, M. (1986), Some comments on recent contributions on capital accumulation, income distribution and capacity utilization, Political Economy: Studies in the Surplus Approach, 2(2), 161-186.

D’Antonio, M. (1973), Sviluppo e crisi del capitalismo italiano - 1951-1972, De Donato, Bari.

D’Antonio, M. (1997), La politica economica degli anni Sessanta ovvero le occasioni perdute, in: M. Arcelli (ed.), Storia, economia e società in Italia - 1947-1997, Laterza, Bari.

Eatwell, J. and Milgate, M. (eds) (1983), Keynes's Economics and the Theory of Value and Distribution, Duckworth, London.

Fratini, S.M. (2016), Sraffa on the Degeneration of the Notion of Cost, Centro Sraffa Working Papers, no. 21.

Freitas, F. and Serrano, F. (2015), Growth rate and level effects, the adjustment of capacity to demand and the Sraffian Supermultiplier, Review of Political Economy, 27(3), 258-281.

Freitas, F. and Serrano, F. (2017), The Trouble with Harrod: the fundamental instability of the warranted rate in the light of the Sraffian Supermultiplier, UFRJ-IE Discussion Paper, no. 018.

Garegnani, P. (1960), Il capitale nelle teorie della distribuzione, Giuffré, Milano.

Garegnani, P. (1962), Il problema della domanda effettiva nello sviluppo economico italiano, Svimez, Roma.

Garegnani, P. (1964-65), Note su consumi, investimenti e domanda effettiva, Economia Internazionale, 17, 591-631 and 18, 575-617.

Garegnani, P. (1976), On a change in the notion of equilibrium in recent work on value, in: M. Brown, K. Sato and P. Zarembka (eds), Essays in Modern Capital Theory, North-Holland, Amsterdam. 
Garegnani, P. (1978-79 [1983]), Notes on consumption, investment and effective demand, parts I and II, Cambridge Journal of Economics, 2, 335-353 and 3, 63-82 (references here from the reprint in Eatwell and Milgate, 1983, pp. 21-69).

Garegnani, P. (1979), Valore e domanda effettiva, Einaudi, Torino.

Garegnani, P. (1992), Some Notes for an Analysis of Accumulation, in: J. Halevi, D. Laibman, and E.J. Nell (eds), Beyond the Steady-State, Macmillan, Basingstoke, 47-71.

Garegnani, P. (2015), On the factors that determine the volume of investment, English translation of chapters III \& IV of Garegnani (1962), Review of Political Economy, 27(2), 111-133.

Graziani, A. (2000), Lo sviluppo dell'economia italiana, Bollati Boringhieri, Torino, second edition.

Hein, E. (2017), Autonomous government expenditure growth, deficits, debt and distribution in a neo-Kaleckian growth model, FMM Working Paper, 01-2017, IMK at the Hans Boeckler Foundation, Macroeconomic Policy Institute.

Hicks, J.R. (1950), A Contribution to the Theory of the Trade Cycle, Clarendon Press, Oxford.

Kalecki, M. (1934), On Foreign Trade and 'Domestic Exports', in: Kalecki (1971).

Kalecki, M. (1967), The Problem of Effective Demand with Tugan-Baranowski and Rosa Luxemburg, in: Kalecki (1971).

Kalecki, M. (1971), Selected Essays on the Dynamics of the Capitalist Economy 1933-1970, Cambridge University Press, Cambridge.

Lavoie, M. (2016a), Convergence Towards the Normal Rate of Capacity Utilization in Neo-Kaleckian Models: The Role of Non-Capacity Creating Autonomous Expenditures, Metroeconomica, 67(1), 172-201.

Lavoie, M. (2016b), Prototypes, Reality and the Growth Rate of Autonomous Consumption Expenditures: A Rejoinder, Metroeconomica, 68(1), 194-199.

Magliulo, A. (2007), La politica economica di Ezio Vanoni negli anni del centrismo, Studi e note di economia, 12(1), 77-114.

Moreira, V.G. and Serrano, F. (2017), Domanda efetiva no longo prazo e no processo de acumilacao: o debate sraffiano a partir do projecto de Garegnani (1962), mimeo, available at:

https://www.researchgate.net/publication/320274104_demanda_efetiva_no_lo-go_pr azo_e no_processo_de acumulacao_o_debate_sraffiano_a_partir_do_projeto_de_ga regnani_1962_effective_demand_in_the long_period_and_in_the_process_of_accu mulation the sraffian

Palumbo, A. and Trezzini, A. (2003), Growth without normal capacity utilization, European Journal of the History of Economic Thought, 10(1), 109-135. 
Petri, F. (1994), The Golden Age, investment, efficiency wages: a review article, Economic Notes, 23, 142-159.

Petri, F. (2001), Pierangelo Garegnani, in: P. Arestis and M.C. Sawyer (eds), A Biographical Dictionary of Dissenting Economists, Edward Elgar.

Robertson, D.H. (1915), A Study of Industrial Fluctuation (London: P. S. King \& Son), Series of Reprints of Scarce Works on Political Economy No. 8, London School of Economics 1948.

Serrano, F. (2008), Kalecki y la economia americana en los anos 2000, Circus, 1, 7-24.

Sraffa, P. (1951), Introduction, in: Ricardo, D., The Works and Correspondence of David Ricardo, Volume 1, edited by P. Sraffa with the collaboration of M.H. Dobb, Cambridge University Press, Cambridge.

Sraffa, P. (1960), Production of Commodities by Means of Commodities. Prelude to a Critique of Economic Theory, Cambridge University Press, Cambridge.

SVIMEZ (with Centro Sraffa) (2017), Il ruolo della domanda nello sviluppo: il Mezzogiorno italiano, i Sud del mondo e la crisi dell'Europa, Quaderno SVIMEZ n. 54.

Tortorella, A. (2013), Garegnani: un impegno morale e umano, in: AA.VV. (2013), video available at:

http://www.centrosraffa.org/PierangeloGaregnaniMemorialLecture.aspx

Trezzini, A. (2011), Steady state and the analysis of long-run tendencies: the case of Kaleckian models, in: R. Ciccone, C. Gehrke, and G. Mongiovi (eds), Sraffa and Modern Economics, Vol. 2, Routledge, London.

Vianello, F. (1989), Effective demand and the rate of profits. Some thoughts on Marx, Kalecki and Sraffa, in: M. Sebastiani (ed.), Kalecki's Relevance Today, Macmillan, London.

Vianello, F. (2004), La Facoltà di Economia e Commercio di Modena, in: G. Garofalo and A. Graziani, La formazione degli economisti in Italia (1950-1975), Il Mulino, Bologna.

Vitale, V. (2000), L'attività della SVIMEZ dal 1946 al 1991, Rivista Economica del Mezzogiorno, 14(2), 541-652. 
Author contact information:

Sergio Cesaratto

University of Siena

sergio.cesaratto@unisi.it 